\title{
OCENA WYKORZYSTANIA ZASOBÓW LOKALNYCH GMIN REGIONU GÓR ŚWIĘTOKRZYSKICH W KREOWANIU I INNOWACYJNOŚCI ROZWOJU TURYSTYKI
}

\begin{abstract}
Zarys treści: Zasoby lokalne gmin regionu Gór Świętokrzyskich, oparte są w większości na tradycji i kulturze ludowej oraz bogactwie walorów przyrodniczych i kulturowych. Celem analizy była ocena stanu zasobów lokalnych regionu Gór Świętokrzyskich, których wykorzystanie pobudza procesy kreowania i innowacyjności w rozwoju turystyki. W opracowaniu wykorzystano dane statystyczne pozyskane z BDL GUS za lata 2010-2014, spis stanu zasobów lokalnych zawarty w Katalogu zasobów lokalnych regionu Gór Świętokrzyskich. W pierwszej części pracy omówiono zagadnienia teoretyczne, związane z terminologią uwzględnioną w badaniu oraz dokonano charakterystyki obszaru badań. W drugiej zaprezentowano wyniki badań oceny zasobów lokalnych i ruchu turystycznego.
\end{abstract}

Słowa kluczowe: Zasoby lokalne, turystyka wiejska, dziedzictwo kulturowe, innowacyjność, kreatywność, społeczność lokalna.

\section{Wprowadzenie}

Możliwości rozwoju turystyki są uwarunkowane wieloma czynnikami o zróżnicowanym charakterze. Wśród nich podstawowe znaczenie nadal mają występujące na danym obszarze zasoby i walory turystyczne, które jednak coraz częściej są wynikiem działalności człowieka mającej na celu wykreowanie atrakcji mogących przyciągnąć turystów (Meyer 2010). Bezpośredni i pośredni rozwój turystyki na danym obszarze uwarunkowany jest jego potencjałem. Potencjał turystyczny regionu Gór Świętokrzyskich to nie tylko walory naturalne, ale także zasoby lokalne, które w większości oparte są na tradycjach lokalnych. Od pokoleń każda społeczność gromadzi zasoby, których źródła zawarte są w wiedzy płynącej z nauki, praktyki, obserwacji, doświadczeń, obyczajowości, norm wartości, zwyczajów i tradycji. Ogrom tych zasobów oddziedziczony od poprzednich 
pokoleń wraz z atrakcjami turystycznymi, czyni ten region wyjątkowym i szczególnie predysponuje go do rozwoju turystyki. Zasoby lokalne oznaczają wszystko, co znajduje się w naszym otoczeniu, co kształtujemy, z czego korzystamy, co nam zapewnia utrzymanie, ułatwia życie i jest dla nas inspiracją (Czapiewska 2016).

W artykule podjęto problematykę określenia roli zasobów lokalnych dla rozwoju regionu Gór Świętokrzyskich. Analizie poddano wybrane zasoby przyrodnicze i kulturowe. Celem pracy była ocena stanu zasobów lokalnych regionu Gór Świętokrzyskich, których wykorzystanie pobudza procesy kreowania i innowacyjności w rozwoju turystyki. Podstawą badania były dane liczbowe nt. ruchu turystycznego w latach 2010-2014, spis zasobów lokalnych zawarty w Katalogu zasobów lokalnych regionu Gór Świętokrzyskich. Wykorzystano także dane dotyczące liczby obiektów wpisanych do rejestru zabytków w gminach (2016 r.), z zasobów Oddziału Terenowego Narodowego Instytutu Dziedzictwa (NID) w Kielcach, a także ranking atrakcji turystycznych (2015 r.), pochodzący z Urzędu Marszałkowskiego Województwa Świętokrzyskiego. Otrzymane wyniki analiz, wykorzystane materiały źródłowe oraz literatura przedmiotu umożliwiają podjęcie próby wskazania tych zasobów lokalnych, które w istotny sposób kształtują rozwój turystyki na obszarze badań.

\section{Istota zasobów lokalnych, innowacyjności i kreatywności w ujęciu teoretycznym}

W literaturze przedmiotu spotykamy wiele definicji zasobów lokalnych. Poszczególni autorzy proponują różne definicje i klasyfikacje. Według A. Nizioł (2016), zasoby lokalne są elementem dziedzictwa danego regionu i kraju, których nie można kupić nigdzie indziej. Stanowią o wartości regionu, są jego bogactwem, które może stać się źródłem przedsiębiorczości i aktywności ludności lokalnej oraz atrakcją i zachętą dla turystów. Badacze powyższej problematyki wskazują na rolę zasobów lokalnych jaką mogą odegrać w rozwoju gospodarczym, w tym między innymi turystyki. Współcześnie coraz bardziej popularne stają się różne formy innowacyjności wprowadzane do promocji produktów turystycznych opartych na lokalnym potencjale obszarów.

Rozwój badań nad procesami innowacyjności datuje się od lat 60. XX wieku. Za prekursora teorii innowacji uznaje się austriackiego ekonomistę J. Schumpetera (1960), który prowadząc badania nad rozwojem gospodarczym zbadał ścieżki wprowadzania istotnych zmian w zakresie produkcji. Wówczas innowacja miała charakter zdecydowanie techniczno-ekonomiczny i początkowo uwaga badaczy skupiała się na innowacjach $\mathrm{w}$ aspekcie przemysłowym lub technologicznym. Lata 70. XX wieku przyniosły zmianę postrzegania problematyki innowacyjności. W 1979 roku B. Ileczko zwróciła uwagę na konieczność rozpatrywania 
innowacji w szerszym kontekście. Postrzegano je jako zjawisko dotyczące: różnych przejawów życia jednostek (podejście antropocentryczne), organizacji relacji międzyludzkich (podejście społeczne), jako nowości w zakresie przyrody (podejście biotyczne) oraz jako zmiany w technice i technologii (podejście techniczne). W związku z tym nastąpiło przesunięcie postrzegania innowacji z obszarów technologicznych do obszarów związanych z marketingiem i zarządzaniem. W związku ze zmianami jakie zaszły w gospodarce w latach 90 . ubiegłego wieku i dynamicznym rozwojem sektora usług, badania nad innowacyjnością usług zaczęły ewoluować. Sektor ten początkowo uważany był za niepodatny na generowanie innowacji i postępu. Obecnie najbardziej rozwinięte i konkurencyjne gospodarki na świecie charakteryzują się doskonale rozwiniętymi usługami (Kiniorska, Baran, Noga 2015).

Dzisiaj innowacyjność i kreatywność odgrywa coraz to ważniejszą rolę w branży turystycznej, głównie poprzez aktywizującą rolę turystyki w rozwoju społecznym i gospodarczym obszarów wiejskich. Sprzyjają temu społeczno-ekonomiczne przemiany oraz zmieniające się trendy na światowym i krajowym rynku turystycznym. Zdecydowanie odchodzi się od turystyki masowej, na rzecz indywidualnych wyjazdów tematycznych, które są zgodne z osobistymi zainteresowaniami podróżujących. Współczesnemu rynkowi turystycznemu nie wystarcza dostarczenie jakichkolwiek dóbr i usług, muszą one być coraz to lepsze, oszczędniejsze i nietuzinkowe. Według M. Romana (2013), koncentrując się na podmiotach turystycznych należy zauważyć, że są innowacyjne, jeżeli właściciel umie tworzyć nowe produkty oraz skutecznie je promować. Powinien więc posiadać zdolność ciągłego pozyskiwania środków finansowych stosownie do zmian zachodzących w otoczeniu. Szczególne miejsce wśród tych zadań zajmuje bezpośredni kontakt $\mathrm{z}$ zasobami lokalnymi wiejskiego dziedzictwa kulturowego. Różnorodność zasobów, ich potencjał zrodził się z aktywności, kreatywności i innowacyjności pokoleń, które budowały, tworzyły i pomnażały kapitał lokalnej kultury i tradycji. Innowacje są szczególnie istotne w procesie zrównoważonego rozwoju tych terenów, bo dostarczają dóbr nieodzownych w tworzeniu produktów turystyki wiejskiej. Zdaniem K. Jagodzińskiej (2013), innowacja jest realizacją atrakcyjnych nowych pomysłów wypływających z kreatywności. Z tego względu zdolność do kreatywnego i innowacyjnego myślenia w równym stopniu przekłada się na zysk na polu ekonomicznym, społecznym i artystycznym. W ujęciu zaś społeczno-gospodarczym „kreatywność polega na umiejętności tworzenia przez daną społeczność nowych modeli zachowań w biznesie oraz modeli budowania i kultywowania relacji społecznych. Bazując na istniejących zasobach, wprowadzają one jakościową zmianę funkcjonowania systemu społeczno-gospodarczego (Strycharz 2013). Istniejący potencjał zasobów lokalnych można wykorzystać w celu utworzenia produktu turystycznego od podstaw. (np. wioski tematyczne, dla których miejscowe walory mogą stanowić tylko tło czy inspirację), jak 
i stworzenie profesjonalnego otoczenia marketingowego do istniejących walorów przyrodniczych, kulturowych (np. zorganizowanie usług i infrastruktury turystycznej wokół obiektów kultury materialnej i ich promocja). Innowacją może być produkt turystyczny w postaci miejsca (obiektu, obszaru, szlaku), wydarzenia (np. festiwalu, imprezy kulturalnej), usługi lub zespołu usług (np. zorganizowanej wycieczki) (Nuszkiewicz, Roman 2013). Przykłady działań o charakterze innowacyjnym można dostrzec $\mathrm{w}$ produktach flagowych i priorytetowych, które pochodzą z potencjału zgromadzonych zasobów lokalnych gmin regionu Gór Świętokrzyskich. W tworzeniu oferty turystyki wiejskiej uwzględnić należy lokalną specyfikę wsi i regionu, a także wynikające z niej atrakcje oraz różnorodne usługi. Pozwala to na stworzenie wielu lokalnych zróżnicowanych ofert, które dzięki swej różnorodności znaleźć mogą wielu nabywców.

Przybywający do gmin turyści mogą aktywnie korzystać z wielu atrakcji o różnej tematyce, uwalniać swoją kreatywność, realizować pasje. Temat przewodni produktów turystycznych zawsze nawiązuje do dziedzictwa zasobów przyrodniczo-kulturowego obszarów wiejskich. Coraz częściej lokalne produkty stają się też elementami sieciowych produktów turystycznych, których przykładem są szlaki kulturowe i tematyczne. Jest to w ostatnich latach popularna formuła, która według ustalonego tematycznie kryterium łączy obiekty i miejsca wybrane, będące unikatowym i reprezentatywnym przykładem dorobku kulturowego danego regionu, społeczności, grupy etnicznej czy narodu (Nizioł 2016). Przykładem takiej oryginalnej inicjatywy na badanym obszarze regionu Gór Świętokrzyskich jest liniowy produkt turystyczny „Szlak Przygody”. Szlak podzielony jest obecnie na osiem tematycznych Krain: „Talentów”, „Sacrum i Profanum”, „Legend”, „Natury”, „Trzech Rzek”, „Czterech Żywiołów”, „Kultur”, a także „Kraina Świętokrzyskie Poza Szlakiem". W skład krain wchodzi wiele ciekawych, cennych obiektów, np.: Dworek Sienkiewicza w Oblęgorku, Opactwo Cystersów w Wąchocku, Sanktuarium na Świętym Krzyżu. To oryginalna inicjatywa, mająca na celu zapoznanie turystów oraz mieszkańców województwa z bogactwem Ziemi Świętokrzyskiej. Projekt powstał w 2013 roku i wówczas otrzymał tytuł Najlepszego Produktu Turystycznego Roku (Kiniorska, Brambert 2017).

\section{Charakterystyka obszaru badań}

Region Gór Świętokrzyskich to obszar obejmujący Góry Świętokrzyskie wraz z jego mezozoicznym obrzeżem, o całkowitej powierzchni zajmującej 2,8 tys. km² (tj. 23,9\% terytorium województwa). Pod względem fizycznogeograficznym jest on częścią makroregionu Wyżyny Kieleckiej, podprowincji Wyżyny Małopolskiej, prowincji Wyżyny Polski (Kondracki 2002).

Administracyjnie położony jest w północno-wschodniej części województwa świętokrzyskiego, w powiatach: kieleckim (17 gmin), opatowskim (2 gminy), ostrowieckim (1 gmina), skarżyskim (3 gminy), starachowickim (2 gminy) (ryc. 1). 


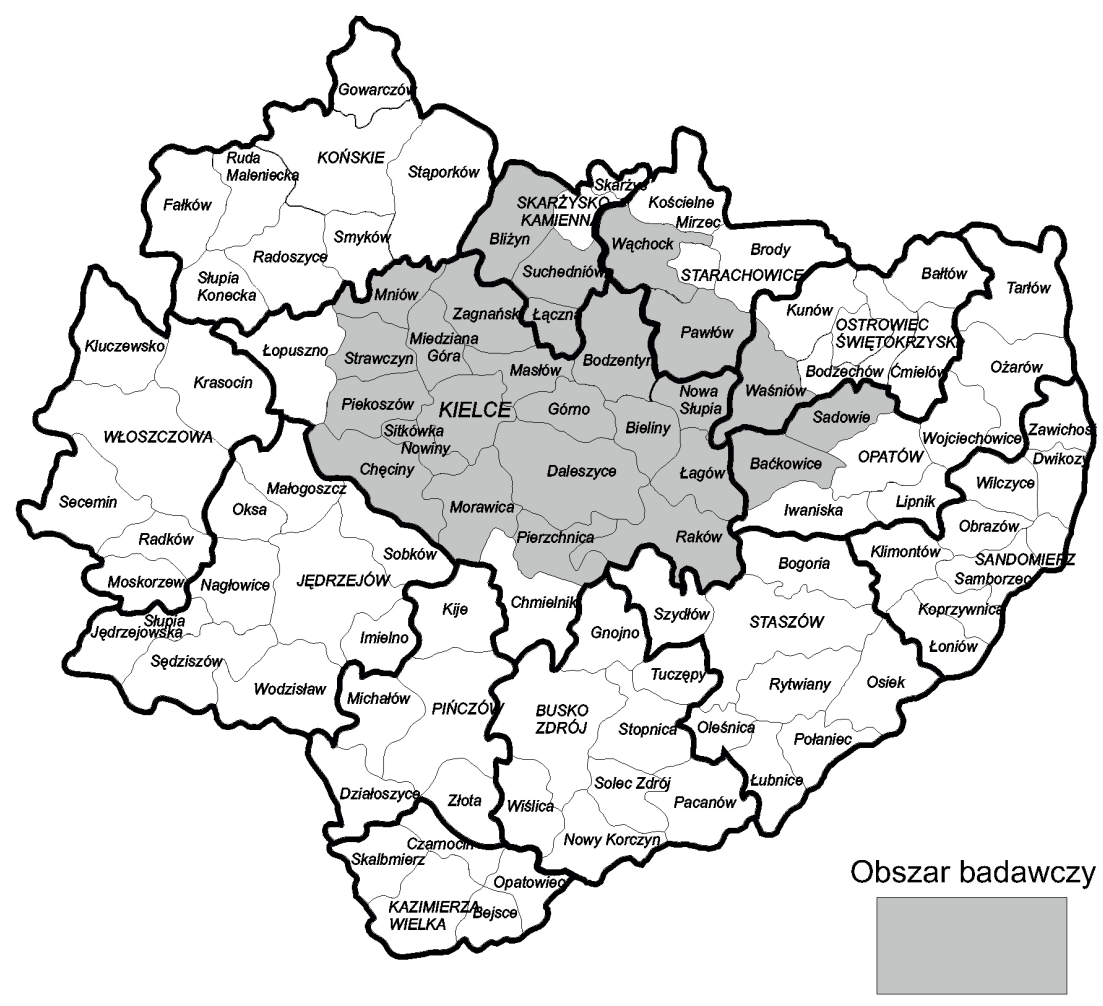

Ryc. 1. Region Gór Świętokrzyskich według podziału administracyjnego Źródło: opracowanie własne

Sieć drogowa regionu jest dobrze rozwinięta. Istnieje dużo różnorodnych połączeń (BUS, PKS, MPK) między miejscowościami wchodzącymi w skład regionu Gór Świętokrzyskich. Układ komunikacyjny stanowią drogi gminne, powiatowe i wojewódzkie. Do głównych dróg krajowych zaliczyć można trasy: nr 7, nr 73 oraz $\mathrm{nr} 74$. Najważniejsze drogi wojewódzkie to: $\mathrm{nr} 763$, nr 745, nr 756, nr 751, nr 764 (Kiniorska, Pałka 2010).

Jest to region o unikatowej budowie geologicznej, zróżnicowanej rzeźbie terenu, warunkach glebowych i skomplikowanych stosunkach hydrogeologicznych. Naturalnymi zasobami przyrodniczymi są tu głównie lasy, bogate w jodłę, świerk, buk i modrzew. Zróżnicowanie terenu i bogactwo szaty roślinnej stworzyło niepowtarzalny, malowniczy krajobraz, który objęty jest różnymi formami ochrony przyrody. W środkowej części regionu utworzono Świętokrzyski Park Narodowy, powstały także cztery parki krajobrazowe: Cisowsko-Orłowiński, Jeleniowski, Sieradowicki i Suchedniowsko-Oblęgorski oraz wiele rezerwatów przyrody. Dla krajobrazu Gór Świętokrzyskich charakterystyczne są strome stoki, gołoborza, skałki ostańców i głęboko wcięte doliny, które nadają im charakterystyczny 
kształt, mimo niewielkiej wysokości bezwzględnej. Określenie „góry” wiąże się w tym przypadku ze strukturą geologiczną, a nie krajobrazem, ponieważ ani wysokości względne, ani bezwzględne nie odpowiadają pojęciu gór, z wyjątkiem części głównej Pasma Świętokrzyskiego (Łysogór), które można zaliczyć do typu gór niskich.

\section{Walory i atrakcje turystyczne}

Zasadniczym źródłem ruchu turystycznego na terenie badań są walory turystyczne. Składają się na nie atrakcje naturalne (krajobraz, klimat) oraz antropogeniczne, wśród których można wyróżnić: architektoniczne (zabytkowa architektura), kulturalne (tradycja i folklor, religia, muzea, imprezy specjalne) oraz społeczne (sposób życia mieszkańców i lokalnej społeczności). Największym potencjałem naturalnym regionu Gór Świętokrzyskich jest różnorodność ukształtowania powierzchni terenu i budowa geologiczna. O jego atrakcyjności świadczą liczne formy ochrony przyrody, w tym m.in.: park narodowy, parki krajobrazowe, obszary chronionego krajobrazu, Natura 2000, rezerwaty przyrody, pomniki przyrody, stanowiska dokumentacyjne, użytki ekologiczne, zespoły przyrodniczo-krajobrazowe. Potencjał przyrodniczy przejawia się przede wszystkim w Świętokrzyskim Parku Narodowym, w jego bioróżnorodności, którą zainteresowani są turyści, tak pod kątem wartości edukacyjnej, wypoczynku, jak i uprawiania turystyki aktywnej. Tylko w Górach Świętokrzyskich znajduje się 26 szlaków pieszych (w tym 105-kilometrowy szlak im. Edmunda Massalskiego, który biegnie przez najciekawsze przyrodniczo i kulturowo miejsca). Potencjał badanego obszaru tkwi również w licznych walorach kulturowych (ryc. 2). Obok kompleksów leśnych występują liczne obiekty architektoniczne, bardzo popularne i często odwiedzane przez turystów. W regionie Gór Świętokrzyskich spotykamy ślady działalności przemysłowej, w tym ruiny wielkiego pieca Bobrzy, miejsca kultu religijnego (grota i kapliczka Św. Rozalii na Górze Perzowej) lub Centrum Edukacyjne „Szklany Dom” - Dworek Stefana Żeromskiego. Jednym z najbardziej popularnych obiektów kulturowych jest Klasztor na Świętym Krzyżu. Należy on do najliczniej odwiedzanych obiektów turystycznych w badanym regionie. W latach 2012-2015 liczba gości zespołu klasztornego wzrosła z poziomu 247,6 tys. do 282,7 tys. osób. W 2015 roku Klasztor Misjonarzy Oblatów Maryi Niepokalanej miał 2. pozycję wśród największych atrakcji turystycznych województwa. Jest on od XIV wieku celem licznych pielgrzymek, ze względu na przechowywane w Sanktuarium relikwie Drzewa Krzyża Świętego. Turyści zwiedzić mogą głównie barokowo-klasycystyczny kościół pw. Trójcy Świętej z XVIII wieku z Kaplicą Oleśnickich. Należy zaznaczyć, że leżący w centrum Gór Świętokrzyskich zabytkowy kom- 
pleks sakralny został uznany za Pomnik Historii i dnia 15 marca 2017 roku $^{1}$ wpisany na listę najcenniejszych obiektów w Polsce. Obejmuje on pobenedyktyński zespół klasztorny z XV wieku, w tym m.in.: kościół, dzwonnicę, bramę wschodnią, system średniowiecznych dróg, a także przedchrześcijańskie obwałowania kamienne na Łysej Górze (datowane na IX-XI w.), które istniały zanim przybyli benedyktyni ${ }^{2}$. Miejsce to jest uznawane za jedno z najważniejszych na obszarze słowiańszczyzny (Kiniorska, Brambert 2017).

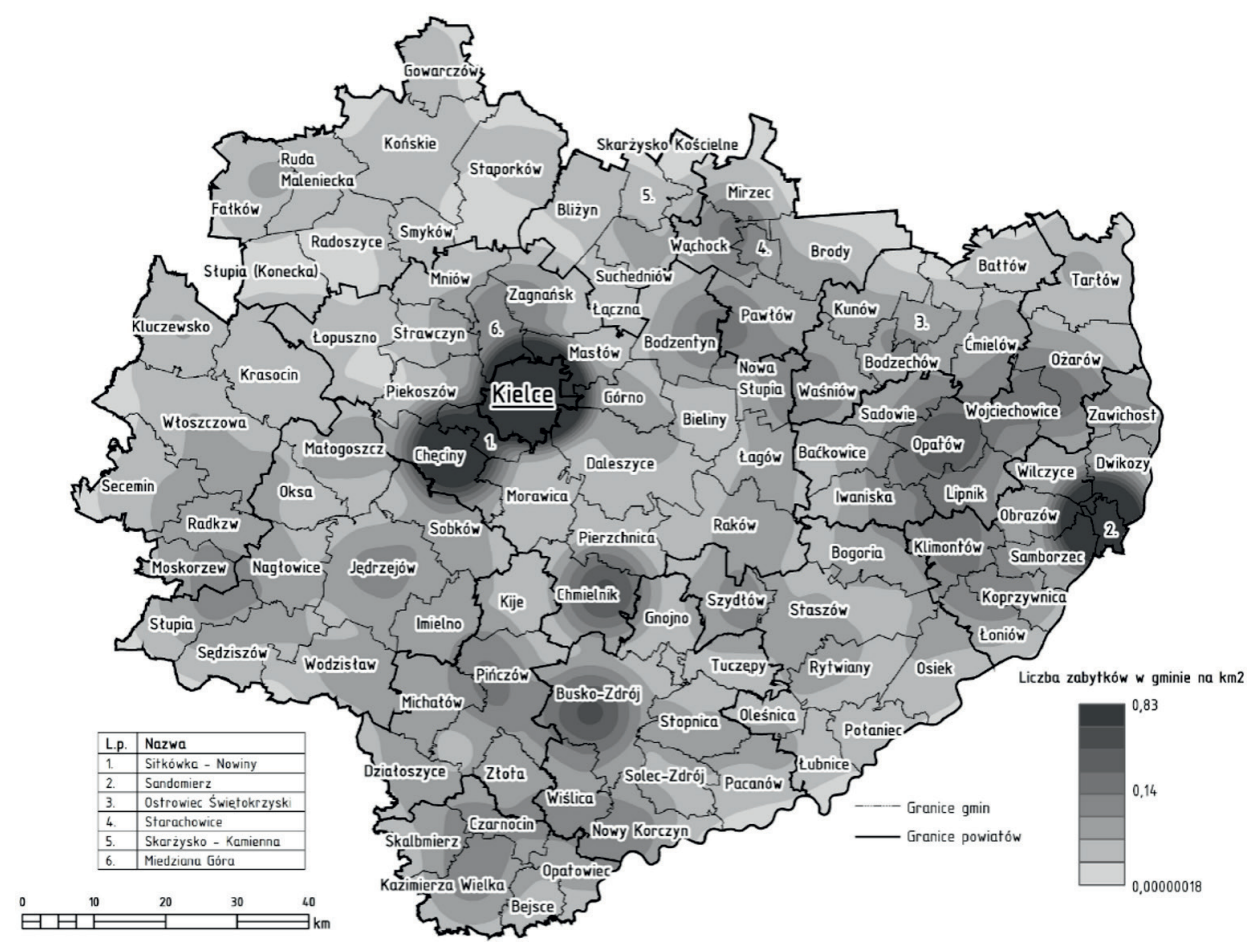

Ryc. 2. Liczba zabytków na jednostkę powierzchni w gminach województwa świętokrzyskiego w 2016 roku

Źródło: I. Kiniorska, P. Brambert (2017) oraz na podstawie danych Oddziału Terenowego NID w Kielcach

\footnotetext{
${ }^{1}$ Rozporzadzenie Prezydenta Rzeczypospolitej Polskiej z dnia 15 marca 2017 roku w sprawie uznania za pomnik historii „Ś więty Krzyż - pobenedyktyński zespół klasztorny oraz przedchrześcijańskie obwałowania kamienne na Łysej Górze” (Dz.U., 28.03.2017, poz. 663).

2 Pełna lista obiektów uznanych za pomniki historii dostępna na: http://www.nid.pl/pl/ Informacje_ogolne/Zabytki_w_Polsce/Pomniki_historii/(dostęp: 20.05.2017).
} 
Ogromnym atutem regionu jest przenikanie się dziedzictwa przyrodniczego i kulturowego. Znacząca jest rola zasobów dziedzictwa antropogenicznego, kształtowana od wieków przez działalność człowieka zarówno w sferze architektury, kultury, gospodarki, jak i szeroko pojętego dziedzictwa umysłowego. Walory antropogeniczne prezentowane są turystom przez ich kreowanie w postaci pokazów, gotowych wyrobów czy eksponowania wielu ciekawych miejsc bogatych w zabytki z różnych epok, w tym m.in.: obiekty sakralne (np. liczące ponad 700 lat Sanktuarium Relikwii Drzewa Krzyża Świętego), zamki, obiekty rezydencjalne, z których wiele funkcjonuje jako elementy produktów turystycznych wzbogacone o ofertę hotelową i gastronomiczną (np. średniowieczna twierdza i późniejszy zamek królewski w Chęcinach), zabytki techniki związane ze Staropolskim Okręgiem Przemysłowym (np. Muzeum Starożytnego Hutnictwa w Nowej Słupi, Muzeum Przyrody i Techniki w Starachowicach), zabytki urbanistyczne (np. średniowieczna urbanistyka w Chęcinach, Bodzentynie), muzea (np. Muzeum Wsi Kieleckiej z Parkiem Etnograficznym w Tokarni, zabytkowa zagroda Czernikiewiczów w Bodzentynie, Mauzoleum Martyrologii Wsi Polskich w Michniowie). Obok stałych ofert dla turystów, uzupełnienie stanowią liczne wydarzenia regionalne. Ogromną popularnością cieszą się różne cykliczne imprezy, np. dni truskawki w Bielinach, dzień tkaczki w Bliżynie, święto chleba w Tokarni koło Chęcin, ziemniaka w Dębie koło Rakowa, dymarki, czy rekonstrukcje historyczne (nawiązujące do starożytnego wytopu żelaza), festyny połączone z rękodzielnictwem ludowym: kowali, garncarzy, rzeźbiarzy, a także pikniki, np. archeologiczny związany z życiem z epoki kamienia koło Wąchocka, kawaleryjski (upamiętniający rocznicę bitwy pod Rogowym Słupem w Bliżynie).

\section{Zasoby lokalne}

Region Gór Świętokrzyskich wyróżnia się unikatową ofertą turystyczną w zakresie dziedzictwa kulturowego, ze względu na bogatą historię związaną z działalnością gospodarczą. Działalność człowieka pozostawiła tu wiele materialnych dowodów świadczących o rozwoju cywilizacji, jak np.: starożytna metalurgia, zabytki kultury żydowskiej i inne. W oparciu o to dziedzictwo budowana jest zróżnicowana oferta turystyczna, która jak dotąd nie wyczerpała wszystkich potencjalnych możliwości ${ }^{3}$. Pod względem etnograficznym region jest zróżnicowany. Społeczność lokalna odziedziczyła majątek kulturowy kilku grup etnograficznych w wyniku uwarunkowań historyczno-politycznych i gospodarczych. To zróżnicowanie przejawia się m.in. w stroju, gwarze, sposobie gospodarowania, mentalności, charakterze zabudowy zagród i wsi. Potencjał tych zasobów obejmuje tak materialne zasoby krajobrazowo-przyrodnicze, kulturowe, społeczne, jak i duchowe, które są wykorzystywane w rozwoju aktywności gospodarczej, inicjatyw lokalnych oraz edukacji (tab. 1, 2, 3, 4).

\footnotetext{
${ }^{3}$ Strategia rozwoju turystyki w województwie świętokrzyskim w latach 2015-2020: 48.
} 
Tabela 1. Wybrane zasoby lokalne (materialne kulturowe) i przykłady ich wykorzystania w regionie Gór Świętokrzyskich

\begin{tabular}{|c|c|}
\hline Podgrupy & Przykłady ich wykorzystania \\
\hline Uprawy, przetwórstwo & $\begin{array}{l}\text { Np. truskawka bielińska uprawiana w Bielinach, Górnie; uprawa } \\
\text { konopi i lnu do produkcji włókna, tkanin, powrozów, sznurów, } \\
\text { płyt paździerzowych w Bodzentynie; owoców np. starych odmian } \\
\text { jabłek, śliw, porzeczek, czereśni na przetwory: dżemy owocowe, } \\
\text { susz owocowy dębniacki, konfitury z owoców jarzębiny, pocho- } \\
\text { dzących z gospodarstw ekologicznych }\end{array}$ \\
\hline Hodowla, przetwórstwo & $\begin{array}{l}\text { Hodowla owiec z wykorzystaniem pożytku: runo owcze na wełnę } \\
\text { do wyrobu pasiaków świętokrzyskich, chust itd., pierze do wyro- } \\
\text { bu kołder i na ubój np. gęsi, gołębi z przetwórstwem wiejskiego } \\
\text { nabiału (sery podsuszane, wędzone), masła i mięsa }\end{array}$ \\
\hline $\begin{array}{l}\text { Obiekty przemysłu } \\
\text { wiejskiego }\end{array}$ & $\begin{array}{l}\text { Małe olejarnie, stosujące tradycyjne metody tłoczenia oleju } \\
\text { np. w Bodzentynie, gręplarnie przy hodowli owiec; kaszarnie } \\
\text { oraz młyny stosujące tradycyjne metody produkcji }\end{array}$ \\
\hline $\begin{array}{l}\text { Przemysł drzewny, } \\
\text { rzemiosło }\end{array}$ & $\begin{array}{l}\text { Ciesielstwo, stolarstwo z umiejętnościami odnawiania starych } \\
\text { domów z zachowaniem ich cech, które kultywowane jest w Świę- } \\
\text { tej Katarzynie, Bielinach, Rakowie i Łącznej }\end{array}$ \\
\hline Zabawki ludowe & $\begin{array}{l}\text { Wyrób drewnianych oraz szmacianych zabawek w oparciu } \\
\text { o miejscowe tradycje, rozpowszechniony w Ostojowie i Łącznej }\end{array}$ \\
\hline Plecionkarstwo & $\begin{array}{l}\text { Wyrób przedmiotów z naturalnych surowców: słomy, rogożyny, } \\
\text { wikliny, korzeni, pędów krzewów i drzew: Daleszyce, Chęciny, } \\
\text { koło Nowej Słupi }\end{array}$ \\
\hline Ceramika i glina & $\begin{array}{l}\text { Wyrób oraz pokazy i nauka zawodu w Chałupkach (gm. Morawi- } \\
\text { ca), Bodzentynie, Daleszycach i Łagowie }\end{array}$ \\
\hline Kowalstwo & Wyrób oraz pokazy i nauka zawodu: Daleszyce i Łagów \\
\hline $\begin{array}{l}\text { Tkactwo oparte } \\
\text { na tradycjach }\end{array}$ & $\begin{array}{l}\text { Otwarzanie, czerpanie wzornictwa i inspiracji z tradycyjnych tka- } \\
\text { nin lnianych i wełnianych, wzorów, faktur, ornamentów na różne } \\
\text { materiały i techniki - okolice Łysogór Bieliny }\end{array}$ \\
\hline Szewstwo & Korzystające ze wzornictwa obuwia tradycyjnego \\
\hline
\end{tabular}

Źródło: opracowanie własne na podstawie Spis rzeczy ważnych. Katalog zasobów lokalnych regionu Gór Świętokrzyskich (2012: 18-40); www.powiatkielecki.pl

Materialne zasoby kulturowe zawierają szereg upraw płodów rolnych, z których powstają produkty spożywcze $\mathrm{i}$ ich przetwórstwo. Wiele $\mathrm{z}$ nich wpisane jest na listę produktów tradycyjnych, które są promowane w ramach Sieci Dziedzictwo Kulinarne Świętokrzyskie (np. wyroby tradycyjne „U Bogusia” w Łosieniu, piekarnia „Tradycja i Zdrowie” w Bodzentynie) jako potwierdzone zasoby o udokumentowanych lokalnych tradycjach, wymagające działań rozwojowych tak w zakresie produkcji, przetwórstwa, dystrybucji, jak i popularyzowania ich 
walorów i związku z regionem. Żywność ekologiczna pochodząca z przydomowych upraw (stare odmiany drzew owocowych, warzywa), razem z przetwórstwem domowym opartym o wieloletnie tradycje, wzbogaca gospodarstwa agroturystyczne i specjalistyczne oraz gospodarstwa tworzące wspólne oferty turystyczne. Uprawa lnu i konopi oraz ich obróbka, a także hodowla, w tym zwłaszcza owiec i przetwórstwo oraz nawiązywanie do zwyczajów z pogranicza magii i medycyny ludowej urozmaicają ofertę turystyczną. Zasoby materialno-kulturowe stanowią istotny potencjał, który wykorzystywany jest w celach rozwoju aktywności gospodarczej i inicjatyw lokalnych.

Tabela 2. Wybrane zasoby lokalne (społeczno-kulturowe) i przykłady ich wykorzystania w regionie Gór Świętokrzyskich

\begin{tabular}{ll}
\multicolumn{1}{c}{ Podgrupy } & \multicolumn{1}{c}{ Przykłady ich wykorzystania } \\
\hline $\begin{array}{l}\text { Obrzędowość } \\
\text { rodzinna }\end{array}$ & $\begin{array}{l}\text { Wesela z wykorzystaniem tradycyjnych elementów, atrybutów, sym- } \\
\text { boliki z dawnym obrzędem, np. w Miedzianej Górze }\end{array}$ \\
\hline $\begin{array}{l}\text { Obrzędowość } \\
\text { doroczna }\end{array}$ & $\begin{array}{l}\text { Zimowe, wiosenne i letnie obrzędy i zwyczaje związane z cyklem } \\
\text { gospodarczym (np. kolędowanie, ostatki, chodzenie z gaikiem, zielo- } \\
\text { ne świątki, zwyczaje sobótkowe, dożynki itd.) }\end{array}$ \\
\hline Targi i jarmarki & Sprzedaż i promocja produktów lokalnych \\
\hline
\end{tabular}

Źródło: opracowanie własne na podstawie Spis rzeczy ważnych. Katalog zasobów lokalnych regionu Gór Świętokrzyskich (2012: 18-40); www.powiatkielecki.pl

Wśród zasobów społeczno-kulturowych istotne znaczenie odgrywają zwyczaje, z uwzględnieniem tradycyjnych elementów, atrybutów i symboliki związanej z dawnymi obrzędami. Ich kultywowanie stanowi ważny aspekt wzmacniania społeczności lokalnej poprzez widowiska przebiegające według opracowanych scenariuszy, odkrywających symboliczne znaczenie zwyczajów oraz poprzez różne formy edukacji.

Kolejnym przykładem wykorzystania zasobów lokalnych jest popularyzacja starych lokalnych form zdobnictwa wnętrz, w tym dla potrzeb m.in. agroturystyki. Organizacja konkursów oraz edukacja i integracja wokół wspólnych zajęć, często połączona $\mathrm{z}$ mówieniem gwarą i prostymi formami wspólnego muzykowania, śpiewu, opowiadania legend wpływa na umacnianie więzi duchowo-kulturowych.

Wybrane przykłady zasobów lokalnych stanowią ogromne dziedzictwo regionu Gór Świętokrzyskich. Wykorzystywane są one zarówno w działalności gospodarczej, przy podejmowaniu inicjatyw, a także w celach edukacyjnych, co przekłada się na tworzenie produktów, które składają się na bogatą ofertę turystyczną. Tradycję i kulturę regionu Gór Świętokrzyskich pielęgnują także lokalne grupy działania. Na terenie regionu funkcjonuje obecnie sześć Lokalnych Grup Działania, co stanowi 1/3 ich ogółu w województwie, które są 
Tabela 3. Wybrane zasoby lokalne (duchowo-kulturowe) i przykłady ich wykorzystania w regionie Gór Świętokrzyskich

\begin{tabular}{|l|l|}
\hline \multicolumn{1}{|c|}{ Podgrupy } & \multicolumn{1}{c|}{ Przykłady ich wykorzystania } \\
\hline $\begin{array}{l}\text { Sztuka } \\
\text { zdobnicza }\end{array}$ & $\begin{array}{l}\text { Popularyzacja starych form zdobnictwa wnętrz: kwiaty, pająki z bibu- } \\
\text { ły, wycinanki do zdobienia ścian wokół obrazów świętych, firanki do } \\
\text { dekoracji szafek i kredensów }\end{array}$ \\
\hline $\begin{array}{l}\text { Twórczość } \\
\text { artystyczna }\end{array}$ & $\begin{array}{l}\text { Popularyzacja, wykorzystywanie gwary, legend, różne formy muzyko- } \\
\text { wania i śpiewu }\end{array}$ \\
\hline $\begin{array}{l}\text { Pielgrzymki } \\
\text { i odpusty }\end{array}$ & $\begin{array}{l}\text { Wyroby pamiątek, kultywowanie zwyczajów pielgrzymowania i odpu- } \\
\text { stów, np. Św. Krzyż, Daleszyce, Kałków-Godów }\end{array}$ \\
\hline $\begin{array}{l}\text { Elementy } \\
\text { demonologii }\end{array}$ & $\begin{array}{l}\text { Popularyzacja elementów demonologicznych związanych z lokalnymi } \\
\text { tradycjami: sabat czarownic na Łysej Górze }\end{array}$ \\
\hline $\begin{array}{l}\text { Medycyna } \\
\text { ludowa }\end{array}$ & Uprawa ziół i przypraw oraz edukacja zielarska, np. w Bodzentynie \\
\hline
\end{tabular}

Źródło: opracowanie własne na podstawie Spis rzeczy ważnych. Katalog zasobów lokalnych regionu Gór Świętokrzyskich (2012: 18-40); www.powiatkielecki.pl

Tabela 4. Wybrane zasoby lokalne (krajoznawczo-przyrodnicze) i przykłady ich wykorzystania w regionie Gór Świętokrzyskich

\begin{tabular}{ll}
\hline \multicolumn{1}{c}{ Podgrupy } & \multicolumn{1}{c}{ Przykłady ich wykorzystania } \\
\hline Architektura & $\begin{array}{l}\text { Zachowanie elementów dawnego krajobrazu z małą ar- } \\
\text { chitekturą, projektowanie, wykorzystanie starych wzor- } \\
\text { ców, edukacja: chałupy, dwory, studnie, małe kapliczki } \\
\text { przydrożne }\end{array}$ \\
\hline $\begin{array}{l}\text { Ciekawe zjawiska } \\
\text { przyrodnicze }\end{array}$ & $\begin{array}{l}\text { Popularyzacja, oznakowanie miejsc i informacja: rezer- } \\
\text { waty i pomniki przyrody, parki krajobrazowe, jaskinie, } \\
\text { np. Raj pod Chęcinami, jaskinia Zbójecka w Łagowie itd. }\end{array}$ \\
\hline Lasy i zbiorniki wodne & $\begin{array}{l}\text { Sportowe i rekreacyjne wykorzystanie walorów przyrod- } \\
\text { niczych (szlaki rowerowe, jeździeckie, piesze, kajakowe, } \\
\text { narciarskie) oznakowanie i rozwój infrastruktury wokół } \\
\text { nich }\end{array}$ \\
\hline Antyczna metalurgia żelaza & $\begin{array}{l}\text { Popularyzacja, oznakowanie miejsc, informacja, inicja- } \\
\text { tywizualizacji: tworzenie osad średniowiecznych } \\
\text { w Hucie Szklanej w gm. Bieliny, dymarki w Nowej Słupi }\end{array}$ \\
\hline Kamieniarstwo & $\begin{array}{l}\text { Artystyczna obróbka kamienia: słynne ,,marmury kiele- } \\
\text { ckie” w okolicach Chęcin }\end{array}$ \\
\hline $\begin{array}{l}\text { Obróbka kamienia, } \\
\text { minerałów }\end{array}$ & Artystyczne wyroby biżuterii \\
\hline
\end{tabular}

Źródło: opracowanie własne na podstawie Spis rzeczy ważnych. Katalog zasobów lokalnych regionu Gór Świętokrzyskich (2012: 18-40); www.powiatkielecki.pl 
wspólfinansowane z Programów Rozwoju Obszarów Wiejskich. Jedną z najprężniej działających LGD jest Stowarzyszenie Rozwoju Wsi Świętokrzyskiej. Skupia ono 7 gmin zlokalizowanych w granicach 4 powiatów województwa (kielecki, starachowicki, opatowski i ostrowiecki), o powierzchni 0,8 tys. $\mathrm{km}^{2}$ i zaludnieniu wynoszącym 61,4 tys. osób. Relacje partnerskie w LGD budowane są w głównej mierze przez mieszkańców (57 przedstawicieli). W zasięgu ich aktywności jest obszar, którego najważniejszymi mocnymi stronami są: położenie w pobliżu ważnych szlaków komunikacyjnych, bogate zasoby geologiczne i żyzne gleby, walory krajobrazowo-przyrodnicze dla rozwoju turystyki, liczne i cenne zabytki (m.in. Sanktuarium Relikwii Drzewa Krzyża Świętego na Świętym Krzyżu, Zamek Krzyżtopór w Ujeździe). Od północy ze Stowarzyszeniem Rozwoju Wsi Świętokrzyskiej graniczy LGD „Białe Ługi”. Jest największą z badanych grupą działania zarówno pod względem zajmowanej powierzchni $\left(1,12\right.$ tys. $\left.\mathrm{km}^{2}\right)$, jak i liczby mieszkańców (76,3 tys.). Partnerstwo łączy działaczy 7 gmin z powiatu kieleckiego oraz staszowskiego. Do mocnych stron terenu LGD „Białe Ługi” należy położenie pomiędzy dużymi miastami - Kielce, Ostrowiec Świętokrzyski, Sandomierz i Busko-Zdrój, co jest korzystne dla rozwoju lokalnej gospodarki. To również różnorodność form ochrony przyrody, lokalne produkty spożywcze i rękodzielnictwo, które są motorem rozwoju turystyki wiejskiej i ekoturystyki. Głównym celem inicjatyw podejmowanych przez grupy lokalne jest coraz to większe zaangażowanie mieszkańców wsi we wspólne działania na potrzeby lokalnej społeczności. Duży nacisk kładzie się na promocję zasobów lokalnych w zakresie turystyki. Przykładem są licznie organizowane wydarzenia kulturalno-rekreacyjne promujące obszary objęte działaniem grup lokalnych, np. święto chleba, pierogów, jarmarki, warsztaty rzeźbiarskie. Wszystkie lokalne grupy działania funkcjonujące na terenie regionu kładą duży nacisk na promocję i wykorzystanie lokalnych zasobów dla rozwoju turystyki. Przeszłość regionu zachowana i odzwierciedlona w kulturze, tradycji ludowej, zabytkach, bogatej historii, wpływa na dalszy rozwój turystyki, w tym zwłaszcza turystyki kulturowej (Wrońska-Kiczor 2017). Współcześnie turystyka kulturowa jest jednym z przejawów podtrzymywania tożsamości, edukacji regionalnej społeczeństwa oraz generowania dochodów w regionach o dużych walorach przyrodniczych i antropogenicznych (Wójcik 2016). Działalność społeczności lokalnej w regionie Gór Świętokrzyskich tworzy podstawę do działań promocyjnych, które umożliwiają odkrycie wielu miejsc dla turystyki. Podejmowane są liczne inicjatywy mające zachęcić mieszkańców do aktywności na rzecz rozwoju lokalnego. Przykładem jest konkurs „Przyjazna wieś” organizowany w ramach Działania Krajowej Sieci Obszarów Wiejskich. W latach 2010-2014 nagrodzono w Polsce 18 projektów o charakterze wiążącym się z rozwojem funkcji turystycznej. Wśród nich znalazły się dwa projekty pochodzące z badanego regionu. W 2011 roku nagrodę otrzymała gmina Masłów za projekt „Dworek Stefana Żeromskiego 
- Szklany Dom - Ikona regionu świętokrzyskiego, zaś w 2012 roku gmina Nowa Słupia została wyróżniona za realizację pt. „Rewitalizacja terenów dymarkowskich w miejscowości Nowa Słupia” (Kiniorska, Brambert 2017).

\section{Ruch turystyczny}

Mnogość i oryginalność walorów turystycznych uzupełniane są zagospodarowaniem turystycznym, co łącznie przekłada się na ruch turystyczny. Obecny stan wyposażenia w infrastrukturę turystyczną stwarza możliwości organizacji dłuższych lub krótszych pobytów, wpływa na wyższy standard świadczonych usług w obiektach noclegowych, gastronomicznych i uzupełniających. Na obszarze regionu Gór Świętokrzyskich w latach 2010-2014 odnotowano wzrost w liczebności obiektów oraz miejsc noclegowych i stopnia ich wykorzystania (ryc. 3).

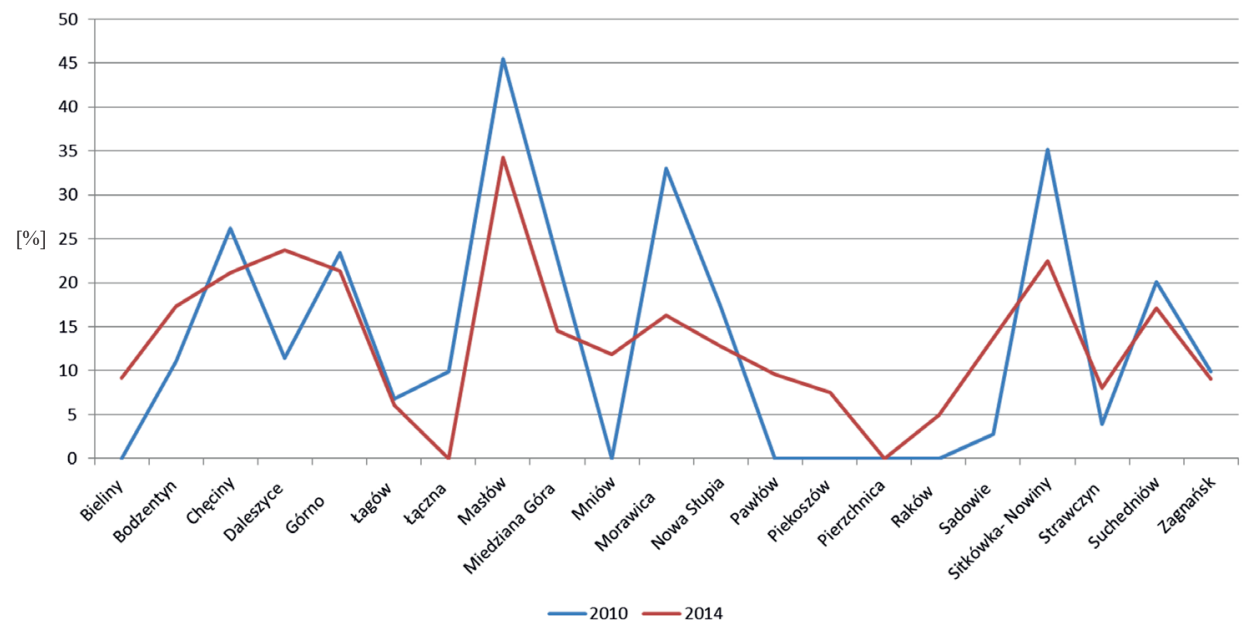

Ryc. 3. Stopień wykorzystania miejsc noclegowych $\mathrm{w}$ gminach regionu Gór Świętokrzyskich w latach 2010 i 2014

Źródło: opracowanie własne

W analizowanych latach liczba obiektów i miejsc noclegowych znacząco wzrosła, tj. obiektów o blisko $78 \%$ (całorocznych o $60,5 \%$ ), a miejsc o ponad 44\% (całorocznych o 34\%). Według kategorii, w 2014 roku ogólna liczba obiektów noclegowych wyniosła 245 (tj. 28,6\% ich ogółu w województwie), a najwięcej z nich - 231 znajduje się na terenie powiatu kieleckiego. Tworzą je głównie gospodarstwa agroturystyczne -159 , hotele -24 , inne obiekty -21 , ośrodki wypoczynkowe -11 , schroniska -9 , motele -4 , pensjonaty -3 i pozostałe 4 . $\mathrm{Z}$ noclegów w 2014 roku skorzystało o $25 \%$ więcej turystów w stosunku do roku

\footnotetext{
${ }^{4}$ Strategia rozwoju turystyki w województwie świętokrzyskim w latach 2015-2020: 68-73.
} 
2010, a o ponad 32\% z zagranicy. Ogólny stopień wykorzystania miejsc noclegowych (mierzony relacją liczby udzielonych noclegów do nominalnej liczby miejsc noclegowych) był w rozkładzie przestrzennym gmin zróżnicowany. Dynamiczne wykorzystanie miejsc notowano w Masłowie, Sitkówce-Nowinach i Chęcinach. W największym stopniu miejsca noclegowe wykorzystywane są w gospodarstwach agroturystycznych oraz schroniskach młodzieżowych. Zwiększony ruch, zwłaszcza $\mathrm{w}$ gminach położonych blisko Kielc, był wynikiem organizacji wielu imprez odbywających się w stolicy, np. Targi Kielce. Na terenie regionu występuje 155 placówek gastronomicznych, z których ponad 68\% zlokalizowana jest głównie w turystycznych obiektach noclegowych (hotelach, zajazdach, motelach). Liczną ofertę gastronomiczną tworzą także bary, gospody oraz punkty gastronomiczne, które z reguły położone są przy szlakach turystycznych w otoczeniu ciekawych miejsc z licznymi walorami kulturowymi. Duże możliwości w zakresie wyżywienia oferują gospodarstwa agroturystyczne, a także całoroczne oraz sezonowe ośrodki wypoczynkowe.

Analiza dynamiki bazy i stopnia wykorzystania miejsc noclegowych wykazała, że rozwój turystyki na badanym obszarze był zróżnicowany przestrzennie. Większość obiektów noclegowych położona jest na terenach powiatu kieleckiego, w bliskim sąsiedztwie Kielc. Pod względem liczby udzielonych noclegów wyróżniały się Daleszyce, Raków, Miedziana Góra, Masłów i Nowa Słupia. Turyści odwiedzający region najczęściej korzystali z noclegów w Daleszycach, Strawczynie, Rakowie i Bodzentynie. Druga dekada XXI wieku należy do intensywnego rozwoju branży turystycznej w regionie. Wzrost liczby obiektów, zwłaszcza bazy noclegowo-gastronomicznej, połączone z promocją i atrakcjami wpłynęły na zwiększony ruch turystyczny.

\section{Podsumowanie}

Lokalny charakter rozwoju w różnych wymiarach: materialnym, społecznym, kulturowym odnosi się do konkretnego miejsca w przestrzeni. Uwarunkowany jest zasobami własnymi jakimi dysponuje określony obszar. Bardzo często o atrakcyjności terenu decydują nie tylko środki finansowe, ale również jakość kapitału ludzkiego i społecznego. Znaczącym elementem są istniejące więzi w obrębie wspólnoty, poczucie związania i tożsamość miejsca. Jak podkreślił w swoich badaniach M. Wójcik (2017), istotą środowiska lokalnego jest sąsiedztwo i wszelkie uwarunkowania życia społecznego, które z niego wynikają. Podejmowane działania inicjatyw społeczności lokalnej przekładają się na wzrost atrakcyjności miejsca, umacnianie tożsamości i rozwój regionu kreatywnego w obszarze turystyki.

W ocenie wykorzystania zasobów lokalnych podkreślono rolę promocji tradycji i kultury regionu Gór Świętokrzyskich. Wskazano działania podejmowane ze strony społeczności lokalnej, której inicjatywy ukierunkowane są na popularyzo- 
wanie odrębności regionalnej, wynikającej z obrzędów i zwyczajów ludowych. W badanych latach wzrosła aktywność lokalnych środowisk podejmujących różne starania $\mathrm{w}$ ramach kreowania produktów turystycznych na rzecz rozwoju regionu Gór Świętokrzyskich. O czym świadczą liczne przykłady imprez, wydarzeń kulturalnych, jak również nagrodzonych projektów, promujących dziedzictwo kulturowe związane między innymi z pisarzem Stefanem Żeromskim i pradawną działalnością gospodarczą. Jednak należy zauważyć, że ta aktywność ograniczona jest jedynie do kilku gmin, położonych w tzw. sercu Gór Świętokrzyskich i wynika również z postawy mieszkańców i aktywności osób działających w lokalnych stowarzyszeniach. W pozostałych gminach badanego regionu, promocja i działalność na rzecz rozwoju turystyki jest niewielka. Wynikać to może z braku pomysłów, mniejszej aktywności mieszkańców lub rozwoju innej formy gospodarki.

\section{Literatura}

Czapiewska G., 2016, Zasoby lokalne regionu pomorskiego i przyktady ich wykorzystania dla wzmocnienia rozwoju społeczno-gospodarczego obszarów wiejskich, „Studia Obszarów Wiejskich", 44: 93-107.

Ileczko B., 1979, Podstawy typologiczne ogólnej teorii innowacji, „Zagadnienia Naukoznawstwa".

Jagodzińska K., 2013, Edukacja kulturalna na rzecz kreatywności i innowacyjności, [w:] Hausner J., Karwińska A., Purchla J. (red.), Kultura a rozwój, Narodowe Centrum Kultury, Warszawa: 327-344.

Kiniorska I., Pałka E., 2010, Wybrane aspekty rozwoju turystyki w regionie Gór Świętokrzyskich, Instytut Geografii, Uniwersytet Humanistyczno-Przyrodniczy Jana Kochanowskiego w Kielcach.

Kiniorska I., Baran E., Noga M., 2015, Innowacyjność gospodarstw agroturystycznych w regionie świętokrzyskim, „Studia KPZK PAN”, 162: 247-263.

Kiniorska I., Brambert P., 2017, Rola turystyki kulturowej w rozwoju gmin województwa świętokrzyskiego, „Zeszyty Naukowe Turystyka i Rekreacja”, 20(2): 75-89.

Kondracki J., 2002, Geografia regionalna Polski, Państwowe Wydawnictwo Naukowe, Warszawa.

Meyer B., 2010, Aktywność samorzadu lokalnego jako element potencjatu turystycznego na przykładzie wybranych gmin województwa zachodniopomorskiego, „Zeszyty Naukowe Uniwersytetu Szczecińskiego. Ekonomiczne Problemy Usług”, 52: 23-32.

Nizioł A., 2016, Rola produktów lokalnych w rozwoju funkcji turystycznej regionu na przykładzie Podkarpacia, „Annales Universitatis Mariae Curie-Skłodowska”, 71: 103-115.

Nuszkiewicz K., Roman M., 2013, Innowacje w rozwoju turystyki, SGGW, Warszawa.

Roman M., 2013, Teoria innowacji i jej zastosowanie w turystyce, [w:] Nuszkiewicz K., Roman M. (red.), Innowacje w rozwoju turystyki, SGGW, Warszawa: 19-27.

Schumpeter J.A., 1960, Teoria rozwoju gospodarczego, Państwowe Wydawnictwo Naukowe, Warszawa.

Spis rzeczy ważnych. Katalog zasobów lokalnych regionu Gór Świętokrzyskich, 2012,

Ośrodek Promowania Przedsiębiorczości, Sandomierz. 
Strategia rozwoju turystyki w województwie świętokrzyskim w latach 2015-2020.

Strycharz J., 2013, Organizacje sektora kultury a rozwój, [w:] Hausner J., Karwińska A., Purchla J. (red.), Kultura a rozwój, Narodowe Centrum Kultury, Warszawa: 175-192. Wójcik M., 2016, Regionalizm w rozwoju wiejskiej turystyki w Polsce, „Studia KPZK PAN", 172: 63-71.

Wójcik M., 2017, Wiedza jako zasób lokalny w środowisku społecznym wsi. Przypadek rodzin rolniczych, „Studia Obszarów Wiejskich”, 45: 159-169.

Wrońska-Kiczor J., 2017, Tradycja i kultura ludowa Nowej Stupi jako istotny element atrakcyjności turystycznej regionu, ,Zeszyty Naukowe Turystyka i Rekreacja”, 20(2): 91-106.

\title{
Źródla internetowe
}

https//mapa.zabytek.gov.pl/nid/ (20.05.2017).

\section{ASSESSMENT OF THE USED LOCAL RESOURCES OF GMINAS IN THE REGION OF THE ŚWIĘTOKRZYSKIE MOUNTAINS FOR CREATING AND INNOVATING DEVELOPMENT OF TOURISM}

\begin{abstract}
Local resources of gminas from the region of the Świętokrzyskie Mountains are predominantly based on tradition and folk culture as well as the wealth of cultural and environmental values. The aim of this analysis was to evaluate available local resources of the region of the Świętokrzyskie Mountains, which boost creation and innovation of development of tourism. It was based on statistical data for the period of 2010-2014 obtained from the Local Data Bank of the Central Statistical Office of Poland, directory of local resources from the Catalogue of Local Resources of the region of the Świętokrzyskie Mountains. The first part presents theoretical background, introduces terminology and describes the area of the study. The second part presents results of evaluation of local resources and tourism.
\end{abstract}

Keywords: Local resources, urban tourism, cultural heritage, innovation, creativity, local community.

Dr Iwona Kiniorska

Zakład Geografii Społeczno-Ekonomicznej

Instytut Geografii

Uniwersytet Jana Kochanowskiego w Kielcach

e-mail: iwona.kiniorska@ujk.edu.pl

Dr inż. Janina Wrońska-Kiczor

Zakład Badań Regionalnych i Gospodarki Przestrzennej

Instytut Geografii

Uniwersytet Jana Kochanowskiego w Kielcach e-mail: janina.wronska@ujk.edu.pl 